\title{
Feelings and Emotions of Nurses Related to Dying and Death of Patients - A Pilot Study
}

\section{Anna Maria Kostka (iD \\ Adriana Borodzicz (i) \\ Sylwia Anna Krzemińska (DD}

Department of Clinical Nursing, Faculty of Health Sciences, Wroclaw Medical

University, Wroclaw, Poland
Correspondence: Sylwia Anna

Krzemińska

Department of Clinical Nursing, Faculty of Health Sciences, Wroclaw Medical University, Bartla 5, Wroclaw, 5|-6|8,

Poland

Email sylwia.krzeminska@umed.wroc.pl
Introduction: The aim of the study, conducted in selected inpatient units, was to evaluate and analyse the feelings and emotions which accompany nurses during their work when they face the death of patients.

Material and Methods: A total of 160 nurses were invited to participate in the study. The study group consisted of 40 nurses from each of the four departments of a municipal hospital: a surgery unit, an internal medicine unit, a hospital emergency department (ER) and an intensive care unit (ICU). A diagnostic survey method was used, including a questionnaire on sociodemographic data as well as questions designed by the author of the research related to the feelings of nurses provoked by the death of patients. To assess the level of anxiety and the ways of coping with stress related to contact with dying patients, Mini-COPE and PSS-10 questionnaires were used.

Results: Compassion, sadness and helplessness are the most common types of nurses' emotions caused by the death of patients, regardless of the nurses' length of service and the place of work. In the study group, $53.90 \%$ of participants experienced a high level of stress. The level of anxiety in nurses from the internal medicine ward was significantly higher than in the nurses from the intensive care unit and the emergency department. The way of coping with stress is related to the period of service and the workplace of nurses.

Conclusion: Nurses experience a high level of stress and strong emotions triggered by the observation of dying patients. Various styles of coping with stress can be noticed depending on job seniority and a place of employment. Due to the emotions evoked by the necessity to deal with death while performing professional duties, it is advisable to develop effective ways of coping in difficult situations.

Keywords: nurses, death, emotions, feelings

\section{Background}

When we think about death, we perceive it as something that usually concerns someone else. Generally, death is associated with loss and one has to come to terms with the reality of dying to be able to live and function properly. It is necessary to reflect on passing away and the end-of-life matters because it allows people to become used to death, at least to some extent. Acceptance of the idea of own death is a manifestation of mental maturity. ${ }^{1}$

Nurses are believed to have more contact with patients than any other healthcare professionals. $^{2}$ In some areas of hospital care, a person needs to be hospitalised several times or the hospitalisation is prolonged due to the patient's condition. This allows nurses to get to know the patients and their families well. The more often nurses meet the patients, the greater is the bond they develop with their patients. 
Dying is an integral and inseparable stage of life. Death has always accompanied human existence. The atmosphere of dying relates to personal fears and feelings which makes the experience particularly distressing and depressing. Passing away is a difficult period in the life of a sick person; it fills with anxiety not only the dying individual but also all those around them. ${ }^{3}$

Death and dying are ubiquitous phenomena in the working environment of nurses. Every death is a painful event but, in a way, it is inscribed in human existence. Nurses often accompany a dying person and they are required to carry out their duties in a professional manner when dealing with such a patient. ${ }^{4,5}$ For nursing staff, such situations are undoubtedly connected with strong emotions and enormous stress.

In 2010 in the United States, the stress of caring for dying patients was the leading cause of high levels of occupational burnout among nurses. ${ }^{6}$

Boerner et al report that the emotions associated with the patient's death play a major role in occupational burnout in long-term care workers. ${ }^{7}$

Following the research among Nigerian nurses, Faremi et al confirmed that the death of a patient is one of the most stressful situations in the work of nurses, right after the shortage of staff and equipment. ${ }^{8} \mathrm{Nia}$ et al analysed the level of fear of death among medical personnel and the strategies of coping with it in various conditions. The fear of patients' death is common among medical workers and it is associated with a negative attitude towards caring for a dying patient. ${ }^{9}$ Sarafis et al analysed the relation between the professional stress of nurses and caring behaviour and the quality of life. The research results show that the death of patients, apart from contact with the patient and the patient's family, conflicts with superiors and uncertainty of the therapeutic effect, caused enormous stress, greater than the one experienced in other aspects of work. ${ }^{10}$

There is not much data available in the literature concerning emotions that accompany nurses while working with a dying patient. Besides, there are also only a few articles discussing strategies for coping with the emotions associated with death and dying patients.

Assisting a dying individual in the last moments of his/ her life is not easy, hence the tremendous stress load associated with the difficult circumstances. The ability to find oneself in a situation when a patient passes away, the need to support the person's family, the necessity to deal with one's own emotions - all those factors influence the behaviour of nurses, both as medical professionals and as human beings.
In the current situation of the health care system, the professional group of nurses is among the ones that are most exposed to stress. The sources of stress include shift work that disrupts the natural circadian rhythm, high physical and mental workload, organisational issues at work, problems with interpersonal relations, unsatisfactory salary, unclear directions of professional development, job insecurity, and many others. Nurses who work in the facilities where they have contact with dying patients claim that the death of a person is a source of strong emotions and stress. ${ }^{11}$

In general, the death of a patient is considered one of the professional situations in nursing. However, there is no doubt that, despite an ability of self-control and a calm approach to the issue, there are still some emotions the nurses need to "work through". The most common include a sense of helplessness and abandonment, anger and sorrow. Emotional pain is a stimulus prompting a nurse to limit contact with the dying person and with his/her relatives. The death of patients affects not only the professional dimension of the nurse's functioning but also their private life which may result in a loss of self-confidence and a sense of guilt. ${ }^{12}$

Objective: The aim of the study, which was conducted in selected inpatient units, was to evaluate and analyse the feelings and emotions accompanying nurses during their work when they experience the death of patients.

The eligibility criteria for the study were: work experience in the nursing profession of more than 1 year, employment in one of the above-listed hospital departments, the ability to complete the questionnaire independently, informed consent.

The exclusion criteria were: work experience of less than 1 year, lack of consent to take part in the study.

\section{Material}

There are 230,433 nurses employed in Poland (data as of 31 December 2020). ${ }^{13}$ The sample size was calculated from the group of employed nurses with a confidence level of $95 \%$ and a maximum error of $8 \%$, and it was set at a minimum of 150 people. The study group consists of 160 people, so the criteria were met.

160 nurses participated in the study. The study group consisted of 40 nurses from each of four hospital departments: a surgery unit, an internal medicine unit, an emergency department and an intensive care unit of a municipal hospital. As many as 141 completed questionnaires were eligible for the analysis (the rest of the surveys contained errors or were not filled in properly). 
Each of the surveyed nurses completed the questionnaire in person, assisted by the examiner (without the possibility of asking questions). The sociodemographic data were obtained from a metric that was part of the survey designed by the author of the study.

\section{Ethical Considerations}

All nurses provided informed consent and were informed that they could withdraw from the study at any time. The study was carried out in accordance with the tenets of the Declaration of Helsinki and Good Clinical Practice guidelines. The project was approved by the Bioethics Committee at the Wroclaw Medical University (approval no. KB-687/2018).

\section{Methods}

In the study, a diagnostic survey method was used, including a questionnaire on sociodemographic data as well as questions designed by the author of the study, concerning the feelings of nurses provoked by the death of patients. To assess the level of stress associated with the death of patients and the ways of coping with stress, Mini-COPE and PSS-10 questionnaires were used.

The inventory to measure the ability to cope with stress, Mini-COPE, the Polish adaptation by Juczyński and Ogińska-Bulik ${ }^{14}$ was created based on $\mathrm{COPE}^{15}$ adjusted to the needs of ${ }^{9}$ clinical research. The Polish version of the Mini-COPE tool consists of 28 statements that form 14 different types of strategies to cope with stress. The tool was used to assess typical ways of responding in situations of experiencing severe stress. ${ }^{14}$

The reliability of the original version determined by Carver, ${ }^{15}$ in the majority of scales, is close to 0.70 , also in the case of the Polish version. ${ }^{14}$

To assess the intensity of experienced stress, the PSS-10 scale (Perceived Stress Scale) was used. It consists of 10 questions concerning various feelings related to personal problems and events, behaviour and styles of coping with anxiety. The total score is the sum of all points (from 0 meaning "“never"” to 4 meaning "“very often"). The higher the score, the greater severity of the perceived stress. The scores within the range of $0-13$ points are considered to be low while the results above 19 points are considered high scores. The scores within the range of 14-19 points are considered average. ${ }^{14}$

In the original version of the PSS-10, as defined by Cohen et $\mathrm{al}^{16}{ }^{16}$ the internal reliability of the scale determined based on Cronbach's alpha ranged from 0.84 to 0.86 . In the Polish version, the Cronbach's alpha index was $0.86{ }^{8}$
The test results were obtained from statistical analysis with the use of the chi-square test or the Fisher test (for qualitative variables) and by using the ANOVA method or the Kruskal-Wallis test (for quantitative variables). After detecting statistically significant differences, a post hoc analysis was performed with the Fisher's Least Significant Difference test or Dunn's test. The normality of the variable distribution was verified using the ShapiroWilk test. A significance level of 0.05 was adopted in the analysis and all $\mathrm{p}$ values below 0.05 were interpreted as indicating significant correlations. The analysis was performed in the R software, version 3.5.2. ${ }^{17}$

\section{Characteristics of the Study Group}

The largest group of the respondents were nurses aged between $40-50(41.84 \%)$ and over 50 (29.08\%), with higher education (73.05\%), working in the profession for over 20 years $(54.61 \%)$, in a relationship (71.08\%) (Table 1).

Table I Characteristics of the Respondents

\begin{tabular}{|c|c|c|c|}
\hline \multicolumn{2}{|l|}{ Feature } & \multirow{2}{*}{$\begin{array}{c}\mathbf{N}=|\mathbf{4}| \\
25\end{array}$} & \multirow{2}{*}{$\begin{array}{c}\% \\
17.73 \%\end{array}$} \\
\hline Age & 20-30 years old & & \\
\hline & $30-40$ years old & 16 & $11.35 \%$ \\
\hline & $40-50$ years old & 59 & $41.84 \%$ \\
\hline & Over 50 years old & 41 & $29.08 \%$ \\
\hline \multirow[t]{3}{*}{ Education } & Secondary education & 38 & $26.95 \%$ \\
\hline & First-cycle studies & 70 & $49.65 \%$ \\
\hline & Long-cycle studies & 33 & $23.40 \%$ \\
\hline \multirow{4}{*}{$\begin{array}{l}\text { Job seniority } \\
\text { (years) }\end{array}$} & Up to 5 years & 24 & $17.02 \%$ \\
\hline & $5-10$ years & 17 & $12.06 \%$ \\
\hline & $10-20$ years & 23 & $16.31 \%$ \\
\hline & Over 20 years & 77 & $54.61 \%$ \\
\hline \multirow[t]{2}{*}{ Marital status } & In a relationship & 110 & $78.01 \%$ \\
\hline & Single & 31 & $21.99 \%$ \\
\hline \multirow{4}{*}{$\begin{array}{l}\text { Place of } \\
\text { employment }\end{array}$} & Surgical department & 34 & $24.11 \%$ \\
\hline & Intensive care unit & 39 & $27.66 \%$ \\
\hline & $\begin{array}{l}\text { Hospital emergency } \\
\text { department }\end{array}$ & 35 & $24.82 \%$ \\
\hline & Internal medicine ward & 33 & $23.40 \%$ \\
\hline
\end{tabular}




\section{Study Results}

The death of another person affects every individual. The type of emotions that accompany a person when a relative passes away is different from the feelings experienced in the case when a stranger dies. The nursing profession has frequent contact with death and that also affects emotions. In the study group, $11 \%$ of the nurses admitted that they reacted very emotionally to the death of a patient, nearly $56 \%$ of the respondents stated that they tried to control their emotions, $33 \%$ of the respondents answered that they kept their distance. The research shows that nurses with long service in work manage their emotions best.

According to the survey, the majority of nurses tried to control their emotions. The largest percentage of such answers was recorded in each department: $68.57 \%$ of the nurses from the hospital emergency department, $55.88 \%$ from the internal medicine unit, $55.88 \%$ from the surgery department and 51.28\% from the intensive care unit. In the internal medicine unit and the surgery department, 21.21 and $14.71 \%$ of the nurses, respectively, reacted very emotionally to the death of patients.

The most common emotions associated with the death of a patient that accompany the personnel were compassion, sadness, and helplessness. In the group of nurses with work experience of up to 5 years, the emotions most often experienced when dealing with a dying patient were helplessness $(62.5 \%$ of the respondents), compassion (54.17\%), sadness (54.17\%) and depression (41.67\%). In the group of the respondents with work experience of 6-10 years, the most often indicated emotions were sadness (76.47\%), helplessness (52.94\%) and compassion (52.94\%). In the group with work experience of 11-20 years, the nurses most often experienced compassion (69.57\%), sadness (60.87\%) and helplessness (47.83\%). In the group with more than 20 years of service, the prevailing emotions included compassion (68.83\%), sadness $(58.44 \%)$ and helplessness $(44.19 \%)$.

The emotions that the surveyed nurses did not experience were anger, indifference, and despair. The relationships were not statistically significant $(\mathrm{p}>0.05)$ (Table 2$)$.

Regarding the place of work, the most frequent types of emotions associated with the death of a patient included compassion (79.41\%) and sadness $(76.46 \%)$ in the case of the nurses from the surgery department, compassion $(58.97 \%)$ in the intensive care unit it was, compassion (74.29\%), helplessness $(62.86 \%)$ and sadness $(60 \%)$ in the emergency department, and sadness (60.61\%) and sorrow $(51.52 \%)$ in the internal medicine ward. A type of emotions that the nurses did not experience, in any of the analysed hospital departments, was indifference. Anger and despair are the emotions observed in the surgery department and the intensive care unit while despair was

Table 2 Type of Emotions Evoked in Respondents by the Death of a Patient (Depending on the Length of Service)

\begin{tabular}{|c|c|c|c|c|c|}
\hline \multirow[t]{2}{*}{ Emotions } & \multicolumn{4}{|c|}{ Job Seniority (Years) } & \multirow[t]{2}{*}{$\mathbf{p}$} \\
\hline & $\begin{array}{l}\text { Up to } 5 \text { Years } \\
(\mathrm{N}=24)\end{array}$ & $\begin{array}{c}\text { 6-10 Years } \\
(\mathrm{N}=17)\end{array}$ & $\begin{array}{c}\text { II-20 Years } \\
(\mathrm{N}=23)\end{array}$ & $\begin{array}{c}<20 \text { Years } \\
(\mathrm{N}=77)\end{array}$ & \\
\hline Sadness & $13(54.17 \%)$ & $13(76.47 \%)$ & $14(60.87 \%)$ & 45 (58.44\%) & $0.503 \mathrm{ch}$ \\
\hline Anger & $0(0.00 \%)$ & $0(0.00 \%)$ & I (4.35\%) & $2(2.60 \%)$ & $0.686 \mathrm{~F}$ \\
\hline Sorrow & 7 (29.17\%) & $8(47.06 \%)$ & 9 (39.13\%) & $28(36.36 \%)$ & $0.699 \mathrm{ch}$ \\
\hline Helplessness & $15(62.50 \%)$ & $9(52.94 \%)$ & II (47.83\%) & 34 (44.16\%) & $0.459 \mathrm{ch}$ \\
\hline Compassion & $13(54.17 \%)$ & 9 (52.94\%) & $16(69.57 \%)$ & $53(68.83 \%)$ & $0.391 \mathrm{ch}$ \\
\hline Anxiety & $3(12.50 \%)$ & I (5.88\%) & $3(13.04 \%)$ & $4(5.19 \%)$ & $0.393 \mathrm{~F}$ \\
\hline Calmness & $3(12.50 \%)$ & I (5.88\%) & $2(8.70 \%)$ & 9 (II.69\%) & $0.95 \mathrm{IF}$ \\
\hline Despair & $0(0.00 \%)$ & I (5.88\%) & $0(0.00 \%)$ & I (I.30\%) & $0.337 \mathrm{~F}$ \\
\hline Indifference & $0(0.00 \%)$ & $0(0.00 \%)$ & $0(0.00 \%)$ & $0(0.00 \%)$ & $\mathrm{IF}$ \\
\hline Depression & $10(41.67 \%)$ & $5(29.41 \%)$ & $6(26.09 \%)$ & 20 (25.97\%) & $0.517 \mathrm{~F}$ \\
\hline Discouragement & $4(16.67 \%)$ & $2(11.76 \%)$ & I (4.35\%) & 7 (9.09\%) & $0.548 \mathrm{~F}$ \\
\hline
\end{tabular}

Notes: chi, Chi-square test; F, Fisher's exact test (low values expected in the Table). 
experienced in the hospital emergency unit. There are statistically significant correlations, regarding the experienced feelings, among the surveyed nurses - a feeling of sorrow $(\mathrm{p}=0.024)$, compassion $(\mathrm{p}=0.015)$ and calmness $(\mathrm{p}=0.011)$ (Table 3).

The PSS10 questionnaire allows assessing the intensity of stress that is subjectively perceived. In the study group, $76(53.90 \%)$ out of the 141 participants experienced a high level of stress, $49(34.75 \%)$ - a medium level of stress and $16(11.35 \%)$ - a low level of stress.

No statistically significant relationship was found between the work experience of the respondents and the level of stress related to the patient's death $(\mathrm{p}>0.05)$ (Table 4). The workplace has a statistically significant effect on the level of experienced stress related to the death of a patient. The post hoc analysis showed that the nurses from the internal medicine ward experienced a significantly higher level of stress than the nurses from the intensive care unit and the emergency department $(\mathrm{p}<0.05)$ (Table 4).

The results of the Mini COPE Questionnaire indicate that the ways of coping with stress in the working environment where one can see dying patients, according to the participants of the survey, include active coping strategies and planning strategies (mean between 2 and 3, meaning that the strategies were used "often" and "always"). It turned out that the surveyed nurses tried to get emotional support very often. Planning and acceptance also played a significant role while dealing with stress. The least common practice was the use of psychoactive substances (Table 5).

The research shows that seniority has a significant impact on the choice of a specific way of coping with stress $(p<0.05)$. The post hoc analysis proved that the active coping strategy was more frequently used by the nurses with up to 5 years of work experience rather than by those with more than 20 years of seniority. Planning was also a popular method used by the employees with a shorter length of service (Table 6).

The workplace is also an important factor regarding the ways of dealing with stress ( $p>0.05)$. The post hoc analysis showed, among other things, that the active coping strategy was more frequently used by the staff from the intensive care unit than by those from the surgery and internal medicine departments and it was more popular among the nurses from the emergency department than those working in the internal medicine department. The denial strategy was more commonly used by the respondents working in the internal medicine department rather than by those in the intensive

Table 3 Type of Emotions Evoked in Respondents by the Death of a Patient (Depending on the Place of Work)

\begin{tabular}{|c|c|c|c|c|c|}
\hline \multirow[t]{2}{*}{ Emotions } & \multicolumn{4}{|c|}{ Place of Work } & \multirow[t]{2}{*}{$\mathbf{p}$} \\
\hline & $\begin{array}{l}\text { Department Surgery } \\
\text { Department }(\mathrm{N}=34)\end{array}$ & $\begin{array}{l}\text { Intensive Care } \\
\text { Unit }(\mathrm{N}=39)\end{array}$ & $\begin{array}{c}\text { Hospital } \\
\text { Emergency Ward } \\
(\mathbf{N}=35)\end{array}$ & $\begin{array}{l}\text { Department Internal } \\
\text { Medicine Ward }(\mathrm{N}=33)\end{array}$ & \\
\hline Sadness & 26 (76.47\%) & 18 (46.15\%) & $21(60.00 \%)$ & $20(60.61 \%)$ & $0.073 \mathrm{chi}$ \\
\hline Anger & $0(0.00 \%)$ & $0(0.00 \%)$ & I (2.86\%) & $2(6.06 \%)$ & $0.139 \mathrm{~F}$ \\
\hline Sorrow & 14 (4I. I8\%) & 7 (I7.95\%) & 14 (40.00\%) & 17 (5I.52\%) & $0.024 \mathrm{chi}$ \\
\hline Helplessness & I5 (44.12\%) & 18 (46.15\%) & 22 (62.86\%) & 14 (42.42\%) & $0.294 \mathrm{chi}$ \\
\hline Compassion & 27 (79.4l\%) & 23 (58.97\%) & 26 (74.29\%) & 15 (45.45\%) & $0.015 \mathrm{chi}$ \\
\hline Anxiety & $2(5.88 \%)$ & $2(5.13 \%)$ & 4 (II.43\%) & 3 (9.09\%) & $0.77 \mathrm{~F}$ \\
\hline Calmness & 7 (20.59\%) & I (2.56\%) & I (2.86\%) & $6(18.18 \%)$ & $0.011 \mathrm{~F}$ \\
\hline Despair & $0(0.00 \%)$ & I (2.56\%) & $0(0.00 \%)$ & I (3.03\%) & $0.727 \mathrm{~F}$ \\
\hline Indifference & $0(0.00 \%)$ & $0(0.00 \%)$ & 0 (0.00\%) & $0(0.00 \%)$ & I F \\
\hline Depression & 7 (20.59\%) & 15 (38.46\%) & 9 (25.7I\%) & $10(30.30 \%)$ & $0.38 \mathrm{I} \mathrm{chi}$ \\
\hline Discouragement & 3 (8.82\%) & 5 (12.82\%) & I (2.86\%) & $5(15.15 \%)$ & $0.299 \mathrm{~F}$ \\
\hline
\end{tabular}

Notes: chi, Chi-square test; F, Fisher's exact test (low values expected in the Table). 
Table 4 The Relationship Between the Level of Stress, Seniority and the Workplace

\begin{tabular}{|c|c|c|c|c|c|}
\hline & \multicolumn{4}{|c|}{$\begin{array}{l}\text { PSSI0 } \\
\text { [points] }\end{array}$} & \multirow[t]{2}{*}{ P* } \\
\hline & & Mean $\pm S D$ & Median & Quartile & \\
\hline \multirow[t]{4}{*}{ Job seniority (years) } & Up to 5 years $(N=24)$ & $20.33 \pm 6.65$ & 20,5 & $19-24$ & \multirow[t]{4}{*}{0,888} \\
\hline & $6-10$ years $(N=17)$ & $20.07 \pm 6.37$ & 19 & $16-22$ & \\
\hline & II-20 years $(\mathrm{N}=23)$ & $19.91 \pm 5.09$ & 20 & $16,5-23$ & \\
\hline & $<20$ years $(N=77)$ & $19.42 \pm 4.92$ & 20 & $16-22$ & \\
\hline \multirow[t]{4}{*}{ Place of work } & $\begin{array}{c}\text { Department Surgery Department }(\mathrm{N}=34) \\
\text { A }\end{array}$ & $20.18 \pm 5.7$ & 21 & $17-24$ & \multirow[t]{4}{*}{$\begin{array}{r}0,028 \\
D>B, C\end{array}$} \\
\hline & $\begin{array}{c}\text { Intensive Care Unit }(\mathrm{N}=39) \\
\mathrm{B}\end{array}$ & $18.95 \pm 5.48$ & 19 & $|5-2|$ & \\
\hline & $\begin{array}{c}\text { Hospital Emergency Ward }(\mathrm{N}=35) \\
\text { C }\end{array}$ & $18.6 \pm 6$ & 19 & $15,5-22$ & \\
\hline & $\begin{array}{l}\text { Department Internal Medicine Ward }(\mathrm{N}=33) \\
\text { D }\end{array}$ & $21.4 \pm 3.93$ & 21 & $20-23$ & \\
\hline
\end{tabular}

Notes: *Normal distribution in groups, ANOVA + post hoc analysis results (Fisher's LSD test).

care unit and the emergency department. The cessation strategy, on the other hand, was used more often by the staff of the internal medicine department than by those employed in the intensive care unit and the emergency department. What is more, the method was more often used by the personnel from the surgery department rather than by the emergency department staff (Table 7).

Table 5 Analysis of Individual Strategies of Coping with Stress

\begin{tabular}{|c|c|c|c|c|c|c|c|c|c|}
\hline \multicolumn{2}{|c|}{ Strategy } & \multirow{2}{*}{$\frac{N}{|4|}$} & \multirow{2}{*}{$\begin{array}{l}\text { Mean } \\
2.28\end{array}$} & \multirow{2}{*}{$\begin{array}{l}\text { SD } \\
0.58\end{array}$} & \multirow{2}{*}{$\begin{array}{l}\text { Median } \\
2.5\end{array}$} & \multirow{2}{*}{$\frac{\text { Min }}{1}$} & \multirow{2}{*}{$\frac{\operatorname{Max}}{3}$} & \multirow{2}{*}{$\frac{\text { QI }}{2}$} & \multirow{2}{*}{$\frac{\text { Q3 }}{3}$} \\
\hline I & Active coping strategy & & & & & & & & \\
\hline 2 & Planning & $14 \mid$ & 2.16 & 0.6 & 2 & 0.5 & 3 & 2 & 2.5 \\
\hline 3 & Positive revaluation & $14 \mid$ & 1.85 & 0.63 & 2 & 0.5 & 3 & 1.5 & 2.5 \\
\hline 4 & Acceptance & $|4|$ & 1.93 & 0.57 & 2 & 0.5 & 3 & 1.5 & 2 \\
\hline 5 & Sense of humour & $|4|$ & 0.82 & 0.73 & I & 0 & 3 & 0 & 1.5 \\
\hline 6 & Turning to religion & $14 \mid$ & 1.49 & 0.95 & 1.5 & 0 & 3 & 1 & 2 \\
\hline 7 & Seeking emotional support & $|4|$ & 1.94 & 0.75 & 2 & 0 & 3 & 1.5 & 2.5 \\
\hline 8 & Seeking instrumental support & $14 \mid$ & 1.84 & 0.7 & 2 & 0 & 3 & 1.5 & 2 \\
\hline 9 & Engagement with other activities & 141 & 1.63 & 0.7 & 1.5 & 0 & 3 & 1 & 2 \\
\hline 10 & Denial & $|4|$ & 0.99 & 0.77 & I & 0 & 3 & 0.5 & 1.5 \\
\hline II & Abreaction & $14 \mid$ & 1.37 & 0.68 & 1.5 & 0 & 3 & 1 & 1.5 \\
\hline 12 & Use of psychoactive substances & $|4|$ & 0.45 & 0.73 & 0 & 0 & 3 & 0 & I \\
\hline 13 & Cessation of activities & 141 & 0.93 & 0.72 & I & 0 & 2.5 & 0 & 1.5 \\
\hline 14 & Self-blame & $14 \mid$ & 1.43 & 0.83 & I & 0 & 3 & I & 2 \\
\hline
\end{tabular}




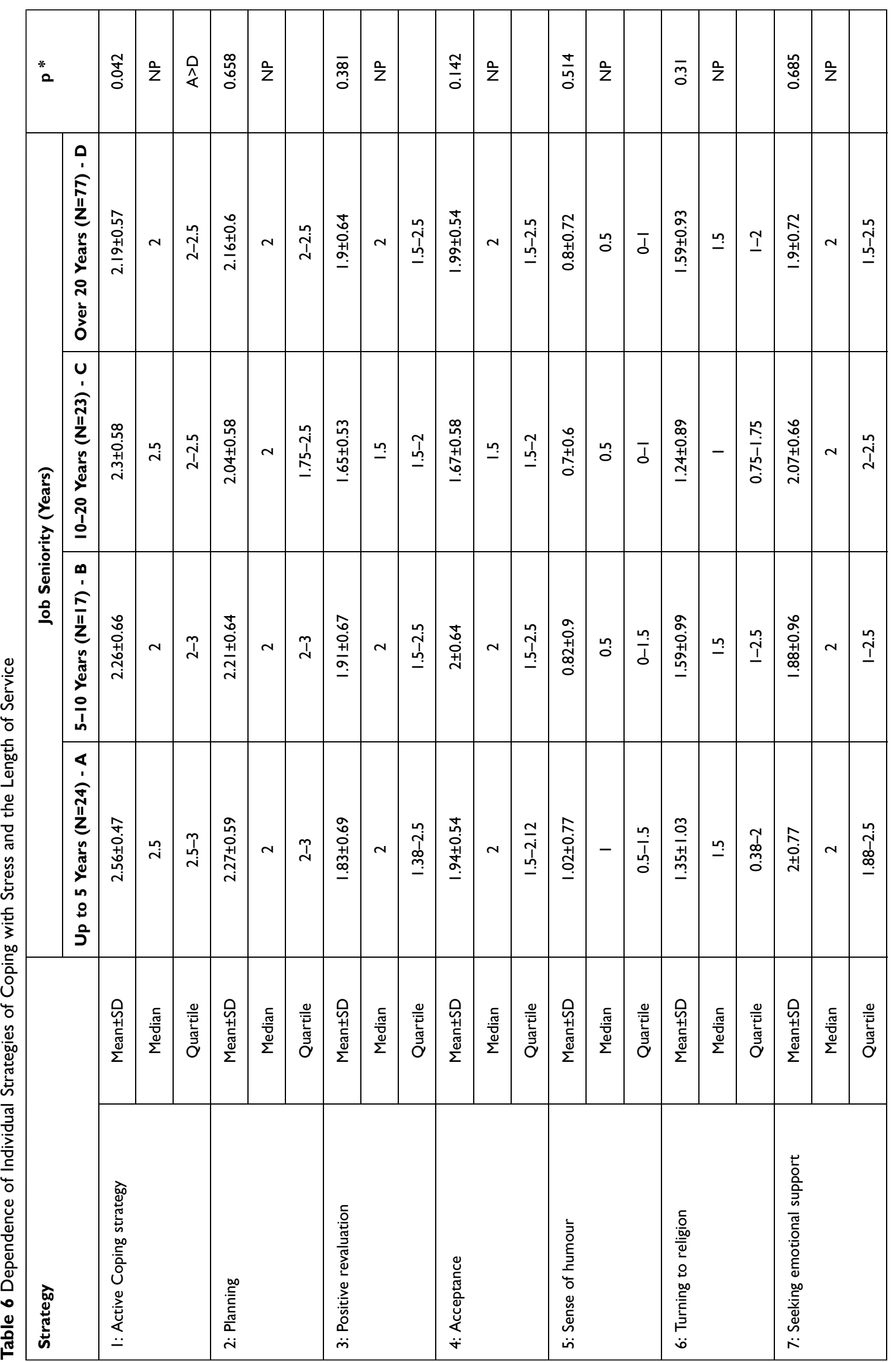




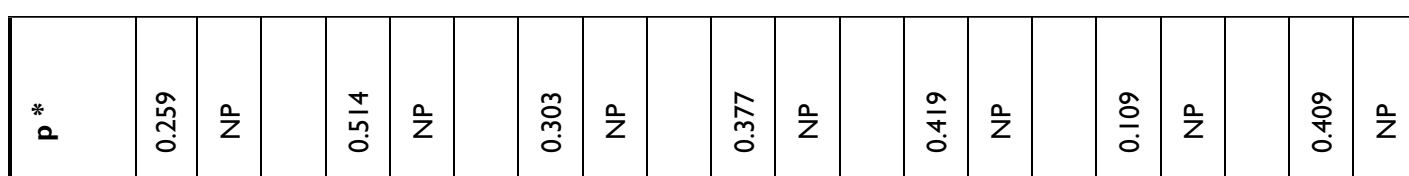

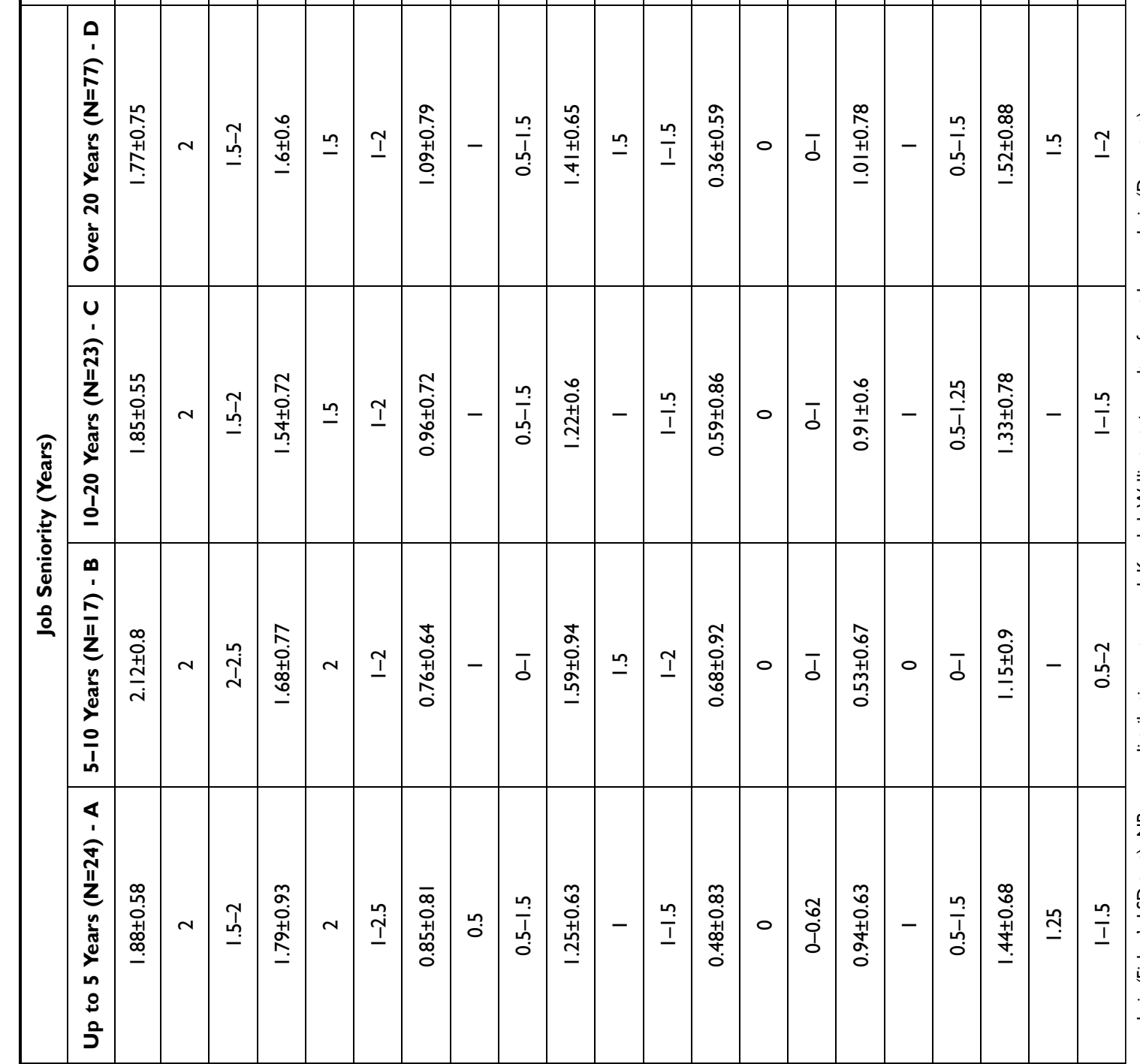

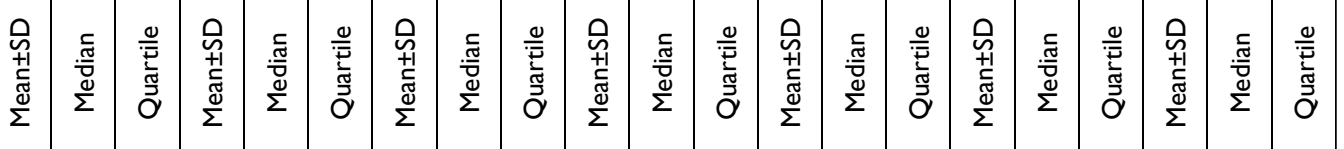

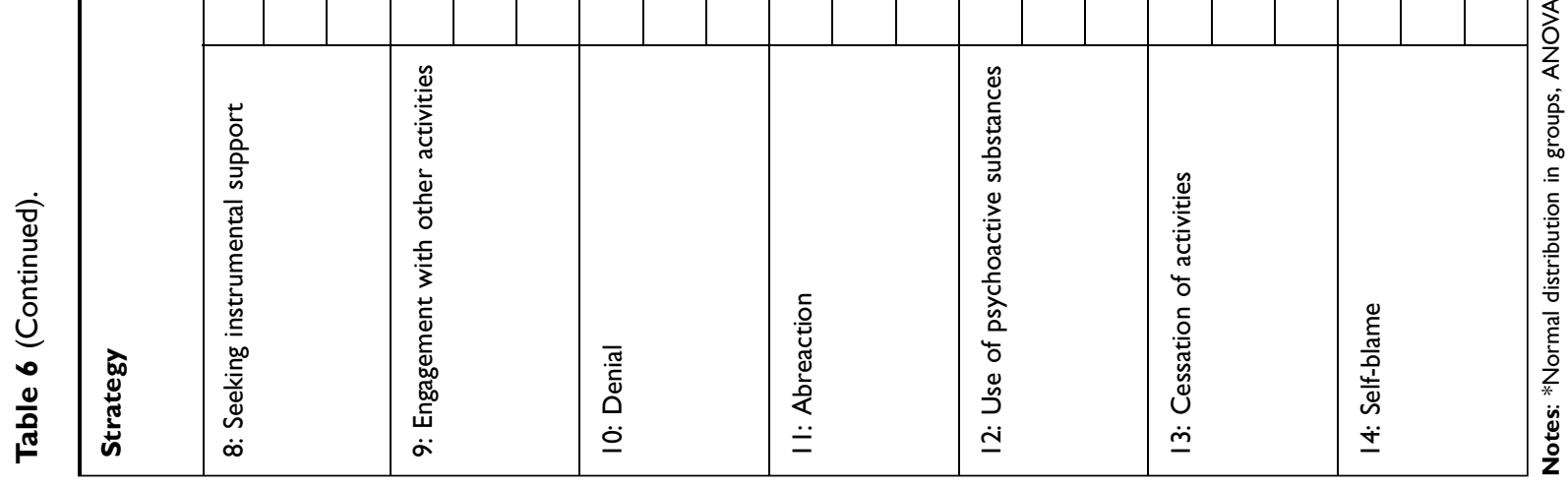




\section{Discussion}

Death of a patient and accompanying him/her during the process of dying are the situations that directly increase the level of anxiety and depression in nurses. The feelings experienced by nurses are a reason for reflection as there are moments that fall deeply in a person's memory. The research on emotions is most often conducted among groups of nurses who accompany patients to the point of death (care or nursing homes, oncology units). ${ }^{18-20}$ On the other hand, such studies are not frequent in the case of personnel of other hospital departments. $^{21,22}$

According to the results of the author's research, the most common feelings associated with death are sadness, compassion and helplessness. The outcome of the study is not influenced by the length of service of the personnel. In Poland, there was research conducted to assess the attitudes of nurses of various specialities related to the death of patients. ${ }^{22}$ The emotions of the staff of different departments were analysed and it was shown that the most common feelings in the majority of the nurses were compassion, sadness, and helplessness. However, it was pointed out that the most significant factors that influenced the level of experienced stress were the age of the dying patient and the cause of death (sudden death or death as a result of chronic diseases).

A study conducted by Glowacka et $\mathrm{al}^{12}$ also shows that the feeling of sadness accompanies virtually all medical personnel. The author also proves that seniority is important in the perception of individual emotions. According to the research, for instance, anxiety is the most common type of emotion experienced by nurses with 20-40 years of seniority. What is more, respondents with the shortest length of service found it very hard to cope with death and they experienced a particularly high level of sense of powerlessness, the feeling that becomes less intensive the longer the person works in the profession.

According to scientists from Jordan, the feelings that are provoked by the death of a patient are most often sadness and sorrow. Additionally, religion and spirituality are very important while dealing with emotions, ${ }^{23}$ which is also confirmed by Makowicz et $\mathrm{al}^{22}$ and MacDermott and Keenan. ${ }^{24}$

According to the author of this study, some persons chose religion as a stress-coping strategy. Those were mainly employees of the analysed departments with less than 5 years of work experience.
The PSS10 questionnaire allows assessing the intensity of stress that is subjectively perceived. Based on the analysis of the survey, it was discovered that more than half $(53.9 \%)$ of the respondents experienced high levels of stress. In the remaining group, the majority of nurses dealt with a medium level of stress $(34.75 \%)$ and much fewer respondents (11.35\%) experienced a low level of anxiety. There was no significant correlation between the level of stress and the length of service. In terms of the workplace, the analysis showed that the employees of the internal medicine department were exposed to a significantly higher level of stress compared to those from the intensive care unit and the emergency department.

Białek and Sadowski ${ }^{25}$ examined the level of stress experienced by the doctors working in the intensive care units in Poland. Nearly 52\% of the respondents dealt with a high level of stress. Planning, an active coping strategy and seeking professional support were the most frequently used methods to cope with stress while denial, turning to religion, cessation of activities or using psychoactive substances were the least frequently indicated solutions.

Wzorek $^{26}$ surveyed nurses working in health centres, neurological and intensive care units. It was observed that persons working in the neurological ward chose the death of a patient as the most stressful factor. According to the responses of the staff of the intensive care unit, a patient's death was not as stressful as resuscitation.

The high level of stress among nurses is also confirmed by the study by Muraczyńska. ${ }^{27}$ The research conducted in 2000 shows that young and inexperienced persons are most vulnerable to stress.

Taking care of dying patients and supporting their families is a difficult and stressful task for nurses who view death as one of the most challenging clinical experiences. Nurses, to be able to cope with such situations, must have the appropriate knowledge, skills and a precise mechanism to deal with a patient. According to the nurses in the Philippines, acceptance, competence, redirection of emotions and experience are also very important. ${ }^{28}$

Own research of the author of the study also shows a significant contribution of acceptance in coping with the stress associated with the death of a patient. However, the most common method used by the respondents to deal with stress was the active coping strategy. This approach was indicated by a majority of the intensive care unit staff as compared with the surgery and the internal medicine 


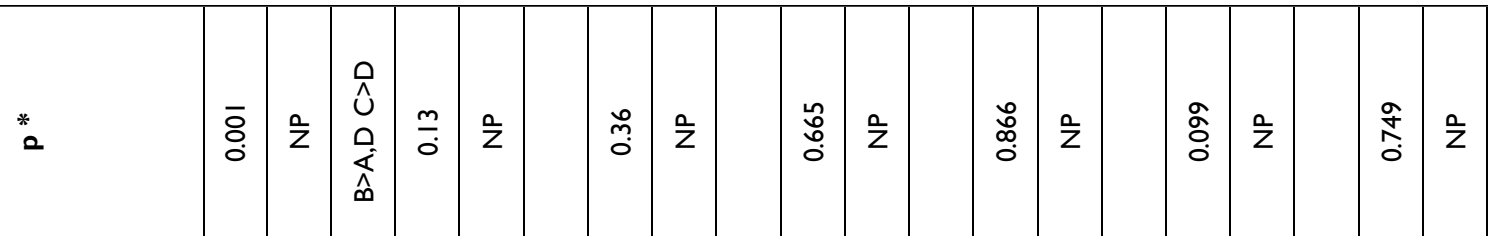

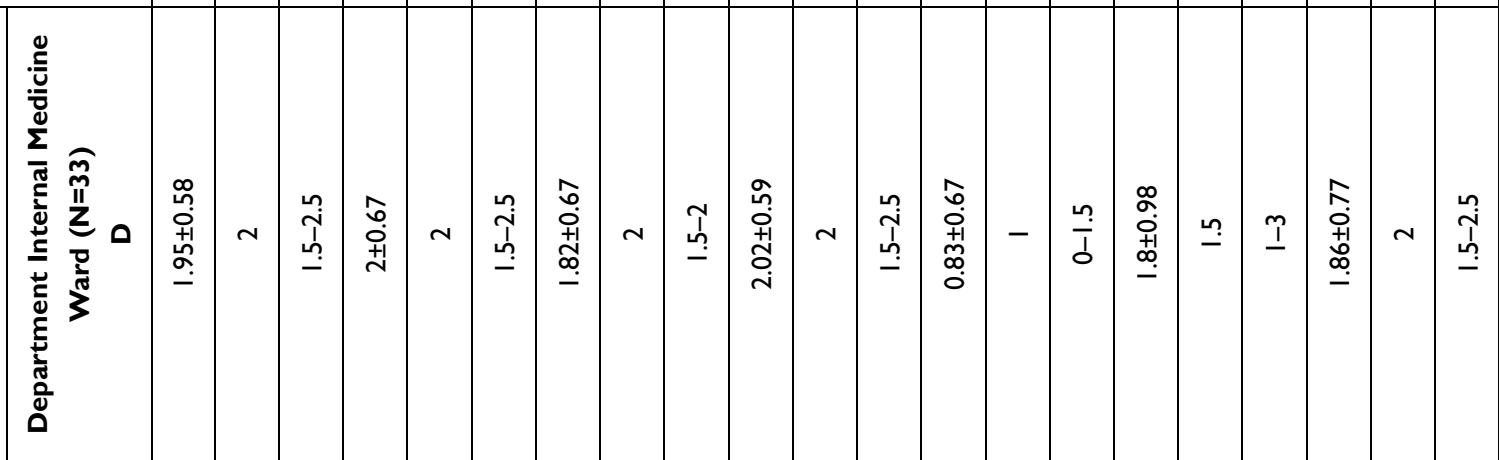

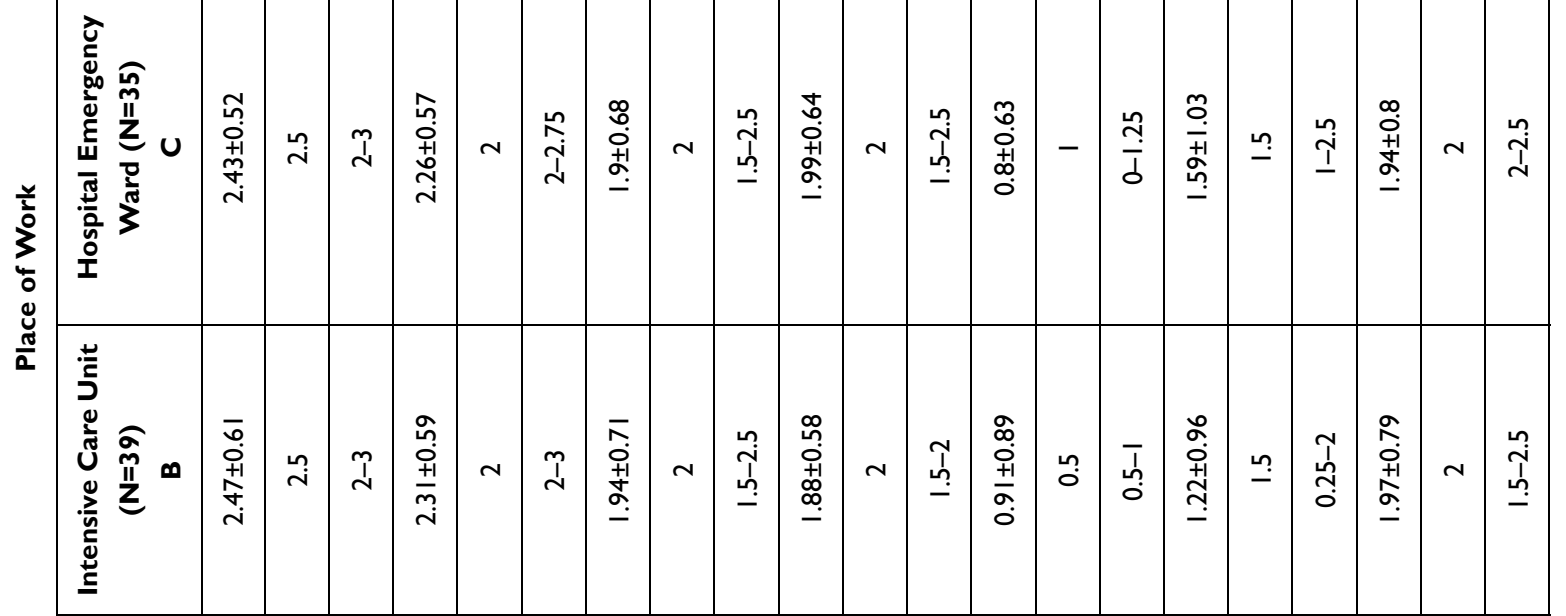

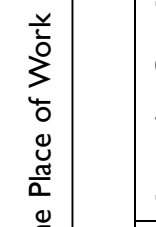

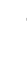

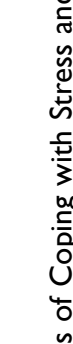

길

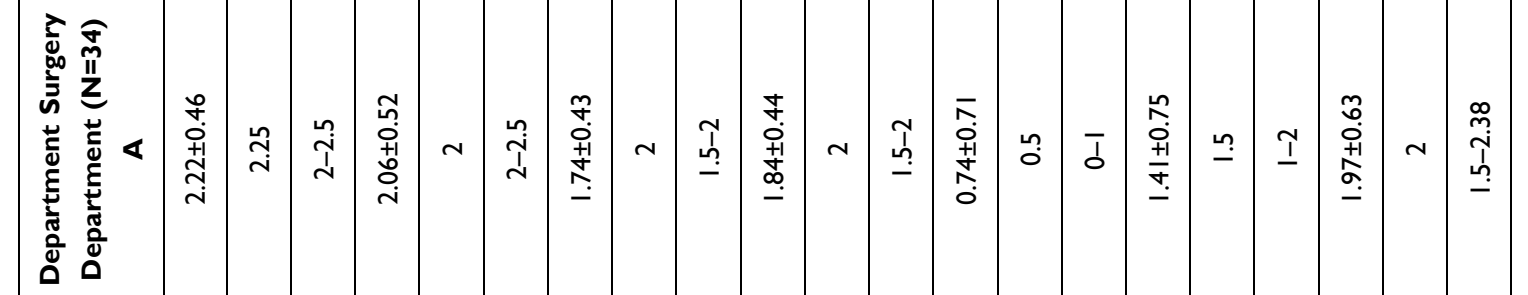

仓ั

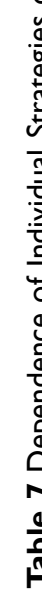

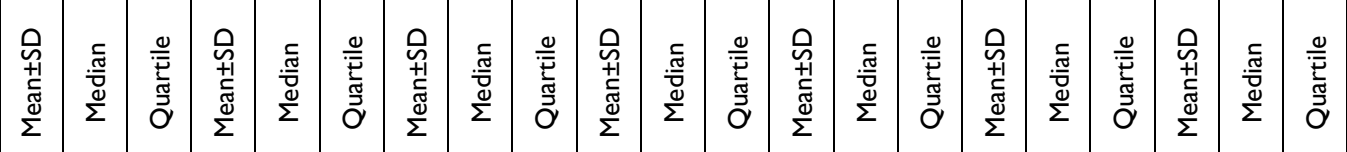




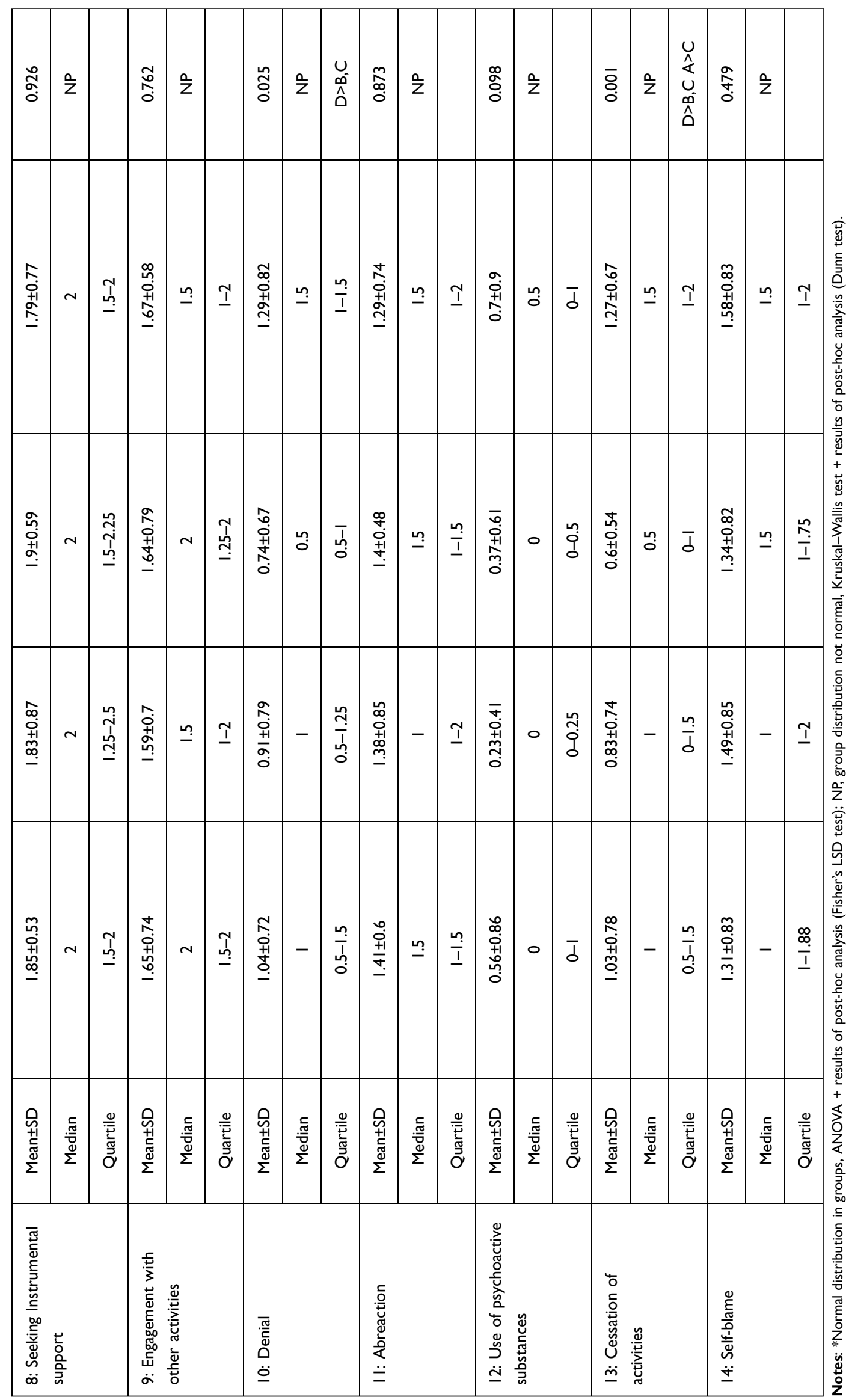


unit. The denial strategy was used more often by the personnel in the internal medicine unit than by those in the intensive care or the emergency departments, similarly to the cessation strategy. In the case of the surgery unit nurses, the cessation strategy was more popular than in the emergency department staff.

According to Czarniecka et al, ${ }^{29}$ death is one of the most stressful situations which the nurses working in the surgery units have to deal with. Among the strategies of dealing with anxiety, active coping strategy, acceptance, and seeking professional support were the most common ones. Only a few of the respondents found consolation in religion helpful. According to the author's study, the importance of religion in the fight against stress is insignificant while an active coping strategy, acceptance or support from professional persons were the methods chosen most often.

Chang $^{30}$ proves in his work the strong importance of social support in coping with the negative experience of the death of a person. The research also shows that the ability to cope with grief related to dying and death is related to seniority and the type of workplace. The author emphasises the important role of support from work colleagues and supervisors who can provide comfort to the nursing staff in coping with the death of patients. ${ }^{29}$ The author's research confirms the great importance of social support in coping with stress.

Powell et al, ${ }^{31}$ who examined the ways the nurses working in palliative care units coped with death, also show the importance of support from other employees. Additionally, it can be noticed that the resistance to stress comes with experience. $^{23}$

Lien et $\mathrm{al}^{32}$ also show that seniority is a crucial factor in choosing the strategies and methods of coping with patients' death. Experience in hospice care is an important predictor of the life attitude of the nurses employed in the intensive care unit and it influences self-efficacy in response to death.

Death and the entire process of dying is a very difficult experience for medical personnel. The stress associated with working with a dying patient and post-mortem care is enormous and requires an appropriate response. Observation and assessment of specific strategies of dealing with stress allow quick response and prevention of depression or professional burnout among nurses.

The Iranian authors point out the need for various psychological and educational interventions among nurses to help them shape strategies to deal with strong emotions and anxiety related to the death of patients. Failure to react in such situations may lead to resignation from the profession and health problems, thus reducing the quality of life. 9

\section{Limitations, Implications, and Suggestions for Future Research}

The limitation of the study is that it was conducted in a group of nurses from one facility only. There is a probability that if the research group was extended to other facilities (larger hospitals in large cities), the results could differ from those obtained.

The number of deaths that the surveyed nurses had contact with at work was also not taken into account. It can be assumed that frequent contact with death and dying increases the level of the related stress.

We suggest that future research should take into account a larger study group, additional factors influencing the perception of death and dying, for example, religion or belief, and the number of deaths.

Based on the obtained results, it seems necessary to enable nurses to work through the emotions resulting from contact with dying patients with a psychotherapist or psychologist who will direct them to the correct perception of death.

\section{Conclusions}

Nurses, regardless of the type of workplace or the length of work experience, face a high level of stress and strong emotions triggered by the observation of dying patients. Various styles of coping with stress are observed depending on job seniority and a place of employment. Due to the emotions evoked by the necessity to deal with death while performing professional duties, it is advisable to develop effective ways of coping with difficult situations.

\section{Acknowledgments}

The research was financed from the funds of the Medical University of Wroclaw: SUB.E020.21.002.

\section{Disclosure}

The authors report no conflicts of interest in this work.

\section{References}

1. Kubitsky J. Help and Survive. Warszawa: Wydawnictwo Lekarskie PZWL; 2017.

2. Costello J. Nursing older dying patients: findings from an ethnographic study of death and dying in elderly care wards. $J$ Adv Nurs. 2001;35 (1):59-68. doi:10.1046/j.1365-2648.2001.01822.x 
3. Seredocha K. Man in the face of death - an anthropological approach. In: Żywucka- Kozłowska E, editor. Death in Many Guises. Olsztyn: Kortowski Przegląd Prawniczy Monografie; 2017:299-305.

4. Ciechaniewicz W. Nursing. Warszawa: Wydawnictwo Lekarskie PZWL; 2010.

5. Sampaio AV, Comassetto I, Faro ACME, Santos RM, Monteiro FS. The experience of nursing students facing death and dying. Invest Educ Enferm. 2015;33(2):305-314. doi:10.17533/udea.iee.v33n2a1

6. Peterson JL, Johnson MA, Halvorsen B, Apmann L. What is it so stressful about caring for a dying patient? A qualitative study of nurses' experiences. Int $J$ Palliat Nurs. 2010;16(4):181-187. doi:10.12968/ijpn.2010.16.4.47784

7. Boerner K, Gleason H, Jopp DS. Burnout after patient death: challenges for direct care workers. J Pain Symptom Manage. 2017;54 (3):317-325. doi:10.1016/j.jpainsymman.2017.06.006

8. Faremi FA, Olatubi MI, Adeniyi KG, et al. Assessment of occupational related stress among nurses in two selected hospitals in a city southwestern Nigeria. Int $J$ Africa Nurs Sci. 2019;10:68-73. doi:10.1016/j.ijans.2019.01.008

9. Nia HS, Lehto RH, Ebadi A, Peyrovi H. Death anxiety among nurses and health care professionals: a review article. Int $J$ Community Based Nurs Midwifery. 2016;4(1):2-10.

10. Sarafis P, Rousaki E, Tsounis A, et al. The impact of occupational stress on nurses' caring behaviors and their health related quality of life. BMC Nurs. 2016;15:56. doi:10.1186/s12912-016-0178-y

11. Tartas M, Derewicz G, Walkiewicz M, Budziński W. Sources of job stress among nurses in hospice and surgical ward. Annales Academiae Medicae Gedanensis. 2009;39:145-153.

12. Głowacka M, Haor B, Ślusarz R, Sotysiak K, Biercewicz M. Śmierć pacjenta jako obciążenie w pracy zawodowej pielęgniarki. Nursing Topics. 2014;22(2):276-280.

13. Naczelna Izba Pielęgniarek i Położnych. Number of registered and employed nurses and midwives. Analyzes and reports. Available from: https://nipip.pl/liczba-pielegniarekpoloznych-zarejestrowanych-zatrudnionych/. Accessed April 16, 2021.

14. Juczyński Z, Ogińska-Bulik N. Tools for measuring stress and coping with stress. In: Pracownia Testów Psychologicznych Polskiego Towarzystwa Psychologicznego. Warszawa; 2009: 45-55.

15. Carver CS, Scheier MF, Weintraub JK. Assessing coping strategies: a theoretically based approach. J Pers Soc Psychol. 1989;56 (2):267-283. doi:10.1037//0022-3514.56.2.267

16. Cohen S, Kamarck T, Mermelstein R. A global measure of perceived stress. J Health Soc Behav. 1983;24(4):385-396. doi:10.2307/ 2136404

17. $\mathrm{R}$ Core Team. R: a language and environment for statistical computing. Vienna, Austria: $\mathrm{R}$ Foundation for Statistical Computing; 2018. Available from: https://www.R-project.org/. Accessed May 24, 2021.
18. Marciniak A, Ślusarska B, Nowicki G. Empathetic skills and coping with cancer patients care difficulties among nurses. Medycyna Paliatywna/Palliative Medicine. 2015;7(3):161-167.

19. Muraczyńska: B. Nurses' professional problems in palliative care selected issues. Ann UMCS Sect I. 2001;15:201-206.

20. Gułag B. Difficult situations in the work environment of nurses and the ability to deal with them. Nurs Public Health. 2004;114 (3):367-370

21. Sleziona M, Krzyżanowski: D. Attitudes of the nurses in the face of patient' dying and death. Nurs Public Health. 2011;1(3):217-223.

22. Makowicz D, Dziubaszewska R, Makowicz N, Barna P, Piękoś: M. The attitude of nursing staff towards the death and dying of the patient. Pielegniarstwo XXI Wieku. 2019;18(3):151-161. doi:10.2478/pielxxiw-2019-0024

23. Khalaf IA, Al-Dweik G, Abu-Snieneh H, et al. Nurses' experiences of grief following patient death: a qualitative approach. $J$ Holist Nurs. 2018;36:228-240. doi:10.1177/0898010117720341

24. MacDermott C, Keenan PM. Grief experiences of nurses in Ireland who have cared for children with an intellectual disability who have died. Int $J$ Palliat Nurs. 2014;20:584-590. doi:10.12968/ ijpn.2014.20.12.584

25. Białek K, Sadowski M. Level of stress and strategies used to cope with stress by physicians working in intensive care units. Anaesthesiol Intensive Ther. 2019;51(5):361-369. doi:10.5114/ ait.2019.90473

26. Wzorek: A. Comparison of the causes of stress among nurses working in wards of different specificity. Studia Medyczne. 2008;11:33-37.

27. Muraczyńska: B. Sources and Intensification of Professional Stress of Nurses at Work with a Dying Man. Vol. 34. Lublin: Annales Universitatis Mariae Curie-Skłodowska; 2000:165-168.

28. Mateo JD, Carlos MA, Chua WRV, et al. "You'll get used to it": a lived experience of Filipino nurses in dealing with death and dying patient. Enferm Clin. 2020;30(Suppl 1):107-112. doi:10.1016/j. enfcli.2019.09.031

29. Czarniecka I, Podsiadły D, Ślusarz R. Occupational stress reactions among nurses working in surgical wards. Innowacje w Pielegniarstwie I Naukach o Zdrowiu. 2018;4:24-28.

30. Chang WP. How social support affects the ability of clinical nursing personnel to cope with death. Appl Nurs Res. 2018;44:25-32. doi:10.1016/j.apnr.2018.09.005

31. Powell MJ, Froggatt K, Giga S. Resilience in inpatient palliative care nursing: a qualitative systematic review. BMJ Support Palliat Care. 2020;10:79-90. doi:10.1136/bmjspcare-2018-001693

32. Lien R, Lu S, Wang Y, Chin S, Shiung T. The relationship between life attitude and death coping self-efficacy in intensive care nurses. J Nurs. 2020;67(5):33-43. doi:10.6224/JN.202010_67(5).06
Psychology Research and Behavior Management

\section{Publish your work in this journal}

Psychology Research and Behavior Management is an international, peer-reviewed, open access journal focusing on the science of psychology and its application in behavior management to develop improved outcomes in the clinical, educational, sports and business arenas. Specific topics covered in the journal include: Neuroscience, memory and decision making; Behavior modification and management; Clinica applications; Business and sports performance management; Social and developmental studies; Animal studies. The manuscript management system is completely online and includes a very quick and fair peer-review system, which is all easy to use. Visit http://www. dovepress.com/testimonials.php to read real quotes from published authors. 